\title{
Managing Problems in Izúcar de Matamoros Valley, Central Mexico, for the Combined Use of Natural and Cultural Landscapes for Tourism as the Key for Local Development
}

\author{
Mariano E. Torres B. \\ Autonomous University of Puebla, Puebla, Mexico
}

\begin{abstract}
The aim of this communication is to present the case of Izúcar de Matamoros Valley, a place in the south of the State of Puebla. This province in central Mexico meets several elements that make it potentially rich for sustainable tourism development. In our study area, a set of both expectations and limitations can be found. This paper is intended to make a model. We list both sides: potential and challenges in order to serve as a framework of analysis for different regions in which there is the same scenario: a rich cultural landscape that poses a great potential and requires different kinds of solutions. Our paper attempts to present a list of tasks and to propose an agenda for regional tourism development. In addition to identifying the main challenges, we are facing this activity. In addition, the paper can be seen as a list of proposals for the improvement of local tourism and ameliorating the quality of life in the area.
\end{abstract}

Keywords: cultural landscape, enhancement, heritage, potential, social challenge

\section{Introduction}

We present the case of Izúcar de Matamoros Valley, a place that is south of the State of Puebla. This province, which is in central Mexico, meets several characteristics that make it potentially rich for sustainable tourism development. In our area of study, we found both a set of expectations and limitations. This paper is intended to make a model to manage common elements in the country, like natural and cultural landscapes, despite being strongly interrelated. We list both sides: potential and challenges in order to serve as a framework of analysis for different regions in which there is the same scenario: a rich cultural landscape that poses a great potential and requires different kinds of solution. The use of this vast range of possibilities is seen as a major challenge, it is no less the coordinating efforts of the three levels of government that exist in Mexico (federal, state, and municipal). Moreover, the participation of the public and private operators is another factor to consider. How to achieve this if we do not start to show them? This research seeks to take this step, while making the prime list of factors and a hierarchy of putting it into action.

Mariano E. Torres B., Dr., Department of Anthropology, Autonomous University of Puebla. Email: mariano.torres@gmail.com. 


\section{The Potential of the Beautiful Valley of Matamoros}

Our case of study is the Izúcar de Matamoros Valley, which is in the south of the Puebla State, in central Mexico. This is an area where the history of local population can date back to several centuries ago. It is, therefore, a region rich in history and landscapes, which also has archaeological sites, historical urban civil monuments, and natural areas with a high biodiversity. However, most parts of this area still do not have legal protection. It is necessary to clarify the category to which each component of the landscape belongs to boost development opportunities that benefit the current population. It is a way to more accurately analyze weaknesses and propose solutions that interoperate with each other gradually optimizing combining efforts and skills of social actors and institutions involved.

\section{The Natural Landscape}

Natural scenery can be seen in all geographical spaces, where human presence and activity are absent or restricted to traffic without intervention (OECD, 2001; Newsome, Moore, \& Dowling, 2012). The literature emphasizes good practices to limit the impact of tourism in protected areas so that it is sustainable. In other words, it would be contradictory to talk about tourism in protected areas. Figure $1^{1}$ shows the areas with a high value ecotourism (green circles) and the areas that need the declaration of protected areas (light green striped area) in the valley of Izúcar of Matamoros, plus an inventory of biotic resources.

Department of Urban Development and Land Use in the municipality of Izúcar de Matamoros had taken the first step already. They are clear about these needs and their dimensions were defined spatially on the map in question. However, it is necessary to establish the guidelines for cooperation between the municipal body, experts, associations, and institutions. This implies an interdisciplinary work that strengthens the performance of public administration on one hand, and the link with the higher education system on the other hand. This task requires the participation of experts from the University of Puebla and her Botanical Garden, the public schools of architecture, civil engineering, and of course tourism and gastronomy schools.

Another important and very difficult problem to solve is related to some prevailing political culture in the country. We focus on the lack of continuity between the public administrations at all levels. At the municipal level of our analysis, another problem is the brevity of this level of government: just three years. This means that large development projects require more encouragement than three years to take place, are not achievable. Every administration seeks to carry out projects involving short deadlines of one or two years. It will be difficult to change the practice of self-promotion of members of the Mexican political class, which considers public works to show their administrative capacity rather than a way of solving the community needs. Always, political men look for to make their own public works while dropping previously launched projects. Their goal is to pretend to show their own virtues leaving aside works initiated by a different political actor. A possible solution will be on the increase in the length of municipal administrations. This would allow for the development of big projects, not only those requiring execution times greater than two years. The increase in the length of municipal administrations also brings time to capture revenue, which certainly means more resources.

\footnotetext{
${ }^{1}$ I thank the Director of Urban Development and Land Management’s 2012-2014 who gave me the map of the "Project triggers" for this research.
} 
In the case of the municipality of Izúcar de Matamoros indeed, they are urgent tasks in order to transform the image of the historic centre. That means the refurbishment of existing roads, streets, pedestrian walkways in the banks, and bridges over the beautiful Nexapa River. These important public works can take advantage of the natural beauty of the river along the Izucar town and stop living behind this lovely view. These enormous works require not only an important amount of money. Maybe the hardest challenge is to solve legal problems such as the invasion of the federal zone of the banks of this splendid river by individuals. However, we can say that the economic and political effort is worthy when we think about the results in the short and long terms.

\section{Theoretical Overview on the Cultural Landscape}

The Izúcar de Matamoros Valley is characterized by its semi-tropical climate, its fertile cane fields, crossed by several rivers and their environment surrounded by hills with a low forest and rangelands. Beyond the limits of the municipality of the same name rest the Epatlán lagoon with fish production and legends like the mermaid that lives and watches this natural beauty. This environment, as an example of a human-nature interaction of several centuries, requires registration work of local knowledge about plants, animals, local legends like the siren and development proposals hostels, viewpoints, etc., in its many natural places, the courses of rivers, canals, and aqueducts.

The study of landscape is quintessential interdisciplinary work. The first use of what we now call cultural landscape dates back to the pioneering work of Sauer (1925). ${ }^{2}$ This method of analysis involves human or cultural events, the study of geography, the physical facts, and natural resources translated into social (such as agricultural land use), periods of transformation of the landscape and its processes.

These actions involving inventory and cataloguing of all this potential, i.e., tasks developing these resources are short and medium term where you can involve stakeholders in the region, to the holders of local knowledge. One such project of inventory can generate jobs for residents. The idea is to open spaces for recreation not only for visitors but above all for the inhabitants of the towns so as to generate inter-regional, social spaces, family life, outdoor sports like hiking, backpacking, mountain biking, fishing, etc.. A world like that is highly desirable and possible.

Obviously, it is also necessary to have specialists from academia, individual farmers, farmers groups and local government levels as auxiliary boards and municipal offices.

\section{Methodological Approach}

Interdisciplinary and inter-institutional work is the key to manage the whole challenges of tourist development in our study case. We can account in the interest of municipal authorities, academic experts in ethnology, anthropology, biology, architecture, and tourism managerial public school. Obviously, this is a teamwork that involves several interests. Our paper and participation in ICOT 2013 Congress was possible thanks to the support of the University of Puebla. But this is just the first step in the definition of the task agenda. At the moment, we collect existing information and scientific works and we start the impulse and assessment of specialized research of participating students who can obtain a degree in the different fields from my position of member of the National Research System (Mexico) and registered researcher of the University of Puebla, in the State of Puebla. We also think it necessary the establishment of a state agency responsible for collecting funds, with powers to propose drafts in the Puebla Heritage rescue and conservation. An office like this needs to exist above periods of municipal and state governments because their duties have to be realized in the long term.

\footnotetext{
${ }^{2}$ For more, please also refer to Leighly (1963).
} 


\section{The Archaeological, Architectural, and Industrial Heritage}

The potential richest of our case study is related to the cultural landscape and the very diverse tangible and intangible heritage.

First, it is important to consider the remaining archaeological remains of the first nations that inhabited the valley. Tepapayeca ruins are quite well known (Garcia Moll, 1993). But there are many other sites with remains in children hood requiring more detailed records and a careful reading to prevent loss (Armella-Spitalier, 2008). During the time of Spanish colonization, indigenous manor importance related to the new elites of European origin and its agricultural wealth attracted the establishment of institutions of the Catholic Church and agricultural entrepreneurs. This colonization and the transformation of existing power structures brought about European material civilization of the time with new farming techniques and marketing products that remain high today such as sugarcane. From this period remain monumental works of religious architecture (Paredes Martinez, 1991).

The most famous monuments are the whole former convent of Santo Domingo and the parish of St. James. However, the list of buildings is broader, comprising also former convent hospital of San Juan de Dios and former convent of the Franciscan Third Order, as well as the respective houses of the 14 indigenous neighbourhoods that made up the city at the colonial era and the temple dedicated to Lord of Calvary built on a nearby hill.

But equally noteworthy are undoubtedly the imposing ruins of old farms, an impressive series of 14 establishments in this valley (Sanchez Cruz, 2007). These buildings dating from the 17th century expect their remains are known, even the beautiful landscapes and contexts that surround them. This set of institutions can play the role of a real magnet for visitors, tours of value added in the region. It is highly likely that once visitor growth is palpable, the recovery of the remains and ruins is given naturally.

Similarly, when recovered buildings will be ready operating as transit stops for hikers, this will naturally induce its restoration to become hotels and restaurants. That happens in the famous Yucatan Peninsula where the almost 1,000 abandoned sisal haciendas start to be transformed into hotels in 1992. Today, we have a range of luxury inns connected as a network of tourist resorts.

In this way, we have not only the necessary investment for restoration and transmission to future generations, but also to enrich the cultural and recreation possibilities in the region. With this proposal, we do not want to give an impression of that being embroidering in the air. The Izúcar de Matamoros Valley is locating in a geographical position, which makes it easily accessible from major cities like Mexico and Puebla. The two major urban centres are actually the main tourist market.

The big question now is: How to increase the tourist flow to give prominence to the potential of the Izúcar of Matamoros Valley and its region? We joint here some elements for an initial strategy.

\section{Strategies and Synergies to Boost Tourism Potential}

In this section, we propose a series of options and opportunities for regional tourism development (Milio Balanzá, 2007). It should be noted that although the emphasis is on the city of Izúcar de Matamoros, the valley of the same name is composed of different municipalities. However, the same type of landscape and climate exists in most of the area. 
Among some strategies that can produce a multiplier effect, we can make a list starting the definition of routes and tracks. The great diversity of elements, both natural landscape, cultural heritage, archaeological, architectural, and industrial heritage, as well as festivals and religious traditions with local cuisine are an intangible cultural heritage, let raise an equally diverse range of routes (Cebrián Abellán, 2008). These can be defined based on specific themes or integrate activities combined, either with visits to the archaeological, architectural, spas, landscapes and natural areas, as well as the nearby Laguna de Epatlán, etc.. The design of these pathways obviously depends on the geographical location of each site. The sequence of the sites included in the tours and the definition of issues increase the chances of supply routes for different types of visitors.

In the specific case of Izúcar de Matamoros Valley, the existence of 14 old buildings and abandoned sugar plantations in the middle of territory is a real network of attractions. However, the restoration of these monuments, despite how urgent it is, involves middle-class investments. The interesting thing here is that such investments commendable in addition to the works of rescue and preservation of heritage are likely to become profitable when used as resting sites such as recreational or sporting activities. And every one of the old farms has different arrangements and requires a specific project that achieves both the restoration and the respectful use of built spaces (Bergeron \& Dorel-Ferré, 1996). In terms of its conservation status, the following can be noted from our visits and Sanchez Cruz's (2007) data.

At the very beginning, we have six haciendas totally ruined and abandoned. That means the haciendas of La Magdalena Tepeojuma, of San Pedro Mártir Ballinas, Hacienda de San Guillermo Jaltepec, Hacienda de San Cosme y San Damián, hacienda de San Juan Atotonilco Raboso and the almost disappeared hacienda of San Andrés. In these cases, their rescue and conservation is of some urgency.

Then, we have five more abandoned haciendas but whose sets retain most of their buildings so they can be recovered almost completely. In this case, we have the haciendas of San José Teruel, San Juan Colón, San Felix Rijo, San Lucas Matlala, and San Nicolás Tolentino. In a third group, we have the haciendas in partial or total use of the old buildings, in this case is the former hacienda of Tatetla Holy Spirit, which works today as a rum factory belonging to the Bacardi Corporation. It is also the case of hacienda Atencingo where we have one of the highest performing mills in the country's sugar production. Finally is the case of the estate of Amatitlanes where a spa which unfortunately has not taken advantage of the beauty of the old building.

The possibilities are endless, we can have spaces for restaurants, inns, hotels, places of outdoor recreation, spas, hiking shelters, etc. (Alfrey \& Putnam, 2013). Obviously, it is necessary to conduct strategic planning to optimize resources, which provides that investments necessarily gradual produce benefits that are re-investible in continuous improvement and increase of the attractions. Obviously, this so wide series of ancient buildings requires very large investments in the long term to be recovered. This fact leads to the need to consider another aspect: the participation of the different levels of authority. This important task needs the combined work of state tourism office with municipal governments.

In this section, we briefly mention the legal and governance aspects. These instances should be support for these regional development efforts and are the only ones with the ability to update the laws protecting historical and cultural heritage and to bring public finances in the infrastructure of the community.

The legal status of each set is crucial to ensure the investments required in the work of rescue and preservation of this old industrial heritage. Historically, we find that several causes led to the abandonment of the old farms. Some were of a technical nature when left to operate the facility with which they had. Others were political-social when where seized agricultural land for distribution in small areas to peasants, leaving the 
costly maintenance resources of the huge buildings. Currently, the real issue is securing the property of each of these historical monuments confidence conducive for investments rescue and conditioning of this heritage. In addition to the necessary laws that protect these buildings for their cultural and historical value, it is necessary to clear the property of each set. This means having very clearly what is private property and which have the status of state property seized. This classification is crucial to define the source of funding.

At the same time, it is necessary to establish a state agency responsible for collecting funds, with powers to propose draft Puebla's State Heritage rescue and conservation of which is necessarily above time periods of municipal and state governments. Indeed, such rescue projects are short, medium and some long-range, obviously beyond the three years of municipal administration and six of state administration. Naturally, an organism like that responsibilities requires approval by the State Congress and a clear definition of its purposes, founding, powers, and autonomy. For such, a momentous work should be recognized by the state authorities of the importance of rescue and conservation of cultural heritage. This involves not just a nostalgic point of view and even romantic. The conservation and transmission of cultural wealth we see in this case also act as a lever of economic development from the tourism, strengthening local cultural life and quality of life for everybody.

Without state participation determined with the legislation, the regulatory and investment in infrastructure for the communities involved; wealth and tourism potential of the region will continue only just as a possibility, more and more vanishing. If the state does not put hands wing work within a short period, it will continue to deteriorate at risk of disappearing, and this loss could be that the cancelation of one good via that can strengthen the development of new sources of wealth.

But how can we plan local development without involving farmers associations?

This section is very specific. It is a call to bring the inhabitants of the region, especially the ejidatarios and their groupings (Pierson, 2007). This implies the participation of local workers from the cleanup and rescue of the sets in ruins until the formation of cooperatives to operate the properties owned by these groups. While training to do work in hospitality and tourism management (Berger \& Eliassen, 2010), it is also necessary to help people appreciate their natural and cultural landscape in which they and their ancestors have influenced.

Obviously, part of the strategic planning of the rescue and recovery projects of regional cultural heritage is to determine when you can invite wholesale travel agencies to include the proposed routes in our case of study in their promotions (Alcazar Martinez, 2005). We said you could not have all the investments needed for this huge work in one step. Similarly, the development of tourist routes will be strengthened with visitor flows that gradually begin to incorporate, so that there is always an invitation to return and discover more and more the richness of the cultural landscape of the beautiful valley of Izúcar de Matamoros.

\section{Final Thoughts}

The Matamoros Valley has an enormous potential in attractive, natural beauty and traces of human settlement dating back to pre-Hispanic times. Academic studies such as this help define and enhance the thematic routes and industrial heritage of the region. However, it is necessary a combined development policy where federal, state, and municipal governments participate, and, of course, the population of the villages living in the area. With this paper, we start the first step and seek forward for the participation of convoluted participants. 


\section{Conclusion}

All elements listed above, the product of historical, ethnographic and geographic research, form an inventory of the items that can boost local development. Our case study is not the only one with a similar set of remains of archaeological, historical, and scenic beauty value, so we consider it as a model rather than singular. Naturally, like any rural community, this needs to reach a diagnosis of local resources and sustainable development proposals. It is necessary the academic research for heritage rescue as well as the coordination of the different levels of government through the exercise of a genuine policy of long-term local development.

\section{References}

Alcazar Martinez, B. (2005). Los canales de distribución en el sector turístico. Madrid: Escuela Superior de Gestión Comercial y Marketing.

Alfrey, J., \& Putnam, T. (2013). The industrial heritage: Managing resources and uses. London: Routledge.

Armella-Spitalier, F. (2008). La antigua Itzocan. Testimonios mesoamericanos. Culturas prehispánicas en Puebla y Morelos. México.

Berger, P. M., \& Eliassen, S. (2010). Hospitality and tourism management. Nova Scientia Pub Incorporated.

Bergeron, L., \& Dorel-Ferré, G. (1996). Le patrimoine industriel. Un nouveau territoire. Paris, Editions Liris.

Cebrián Abellán, F. (2008). Turismo rural y desarrollo local. Sevilla: Publicaciones de la Universidad de Sevilla.

Garcia Moll, R. (1993). Tepapayeca, Puebla. México: INAH.

Leighly, J. (1963). Land and life: A selection from the writings of Carl Ortwin Sauer. Berkeley: University of California Press.

Milio Balanzá, I. (2007). Diseño y comercialización de productos turísticos locales y regionales. Madrid: Paraninfo.

Newsome, D., Moore, S. A., \& Dowling, R. K. (2012). Natural area tourism: Ecology, impact and management (2nd ed.). Bristol: Channel View Publications.

OECD. (2001). Environmental indicators for agriculture (Vol. 3: Methods and results). Retrieved from http://www.oecd.org/tad/sustainable-agriculture/40680869.pdf

Paredes Martinez, C. S. (1991). El impacto de la conquista y colonización española en la antigua Coatlalpan (Izúcar, Puebla) en el primer siglo colonial. México: CIESAS-SEP.

Pierson, J. (2007). Going local: Working in communities and neighbourhoods. London: Routledge.

Sanchez Cruz, M. (2007). Izúcar y sus haciendas. Puebla: Fideicomiso Ingenio de Atencingo.

Sauer, C. O. (1925). Morphology of landscape. Berkeley: University of California Press. 